ties between the respiratory distress syndrome (hyaline membrane disease) in the premature infant and GBS pneumonia and sepsis. To date, there are no reported PAP measurements in infants with GBS sepsis or pneumonia; however, because neonates are born with already thickened pulmonary arteriolar walls and pulmonary vessels very responsive to acidosis, hypoxemia, or hypercarbia, it seems possible that bacterial products from GBS might induce serious pulmonary vascular injury in infected infants. The injury would promote the release of vasoactive mediators such as PG decreasing pulmonary arterial blood flow thus exacerbating the infants' hypoxemia.

\section{REFERENCES AND NOTES}

1. Ablow, R. C., Driscoll, S. G., Effmann, E. L., Gros, I., Jolles, C. J., Uauy, R, and Washaw, J. B.: A comparison of early-onset group B neonatal infection and the respiratory distress syndrome of the newborn. N. Engl. J. Med., 294: 65 (1976).

2. Cefalo, R. C. and Crenshaw, C.: Effects̀ of exogenous estrogen on $\mathrm{PO}_{2}$ and experimental endotoxemia in sheep. Am. J. Obstet. Gynecol. 120: 678 (1974).

3. Cefalo, R. C., Lewis, P. E., O'Brien, W. F., Fletcher, J. R., and Ramwell, P. W.: The role of prostaglandins in endotoxemia: Comparisons in response to the nonpregnant, maternal, and fetal models. Am J. Obstet. Gynecol., 137: $53(1980)$

4. Crook, D., Collins, A. J., Bacon P. A., and Chan, R.: Prostaglandin synthetase activity from human rheumatoid synovial microsomes. Ann. Rheum. Dis., 35: 327 (1976)

5. Ferreira, S. H. and Vane, J. R.: New aspects of the mode of action of nonsteroid anti-inflammatory drugs. Annu. Rev. Pharmacol., 14: 57 (1974).

6. Harrison, L. H., Beller, J. J., Hinshaw, L. B., Coalson, J. J., and Greenfield, L
J.: Effects of endotoxin on pulmonary capillary permeability. Ultrastructure and surfactant. Surg. Gyn. Obstet., 129: 723 (1969).

7. Hellerqvist, C. G., Rojas, J., Green, R. S., Sell, S., Sundell, H., and Stahlman, M. J.: Studies on group B beta hemolytic Streptococcus. I. Isolation and partial characterization of an extracellular toxin. Pediatr. Res., 15:89 (1981).

8. Hemming, V. G., McCloskey, D. W., and Hill, H. R.: Pneumonia in the neonate associated with group B streptococcal septicemia. Am. J. Dis. Child., 130: 1231 (1976).

9. Lancefield, R. C.: Two serological types of group B streptococci with related, but not identical, type specific substances. J. Exp. Med., 67: 25 (1938).

10. Latour, J-G and Leger-Gauthier, C.: Prostaglandins in the pathogenesis of the generalized Schwartzman reaction. Am. J. Obstet. Gynecol., 135:577 (1979).

11. O'Brien, W. F., Cefalo, R. C., Lewis, P. E., Fletcher, J. R., and Ramwell, P. $\mathrm{W} .:$ The role of prostaglandins in endotoxemia and comparisons in response in the nonpregnant, maternal and fetal models. Am. J. Obstet. Gynecol., 138: $535(1981)$

12. Pritchard, D. G., Coligan, J. E., Speed, S. E., and Gray, B. M.: Carbohydrate fingerprints of streptococcal cells. J. Clin. Microbiol., 13: 89 (1981).

13. Rojas, J., Green, R. S., Hellerqvist, C. G., Olegard, R., Brigham, K. L., and Stahlman, M. T.: Studies on group B beta hemolytic Streptococcus. II. Effects on pulmonary hemodynamics and vascular permeability in unanesthetized sheep. Pediatr. Res., 15: 892 (1981).

14. Selye, H., Tuchweber, B., and Bertok, L.: Effect of lead acetate on the susceptibility of rats to bacterial endotoxins. J. Bacteriol., 91: 884 (1966).

15. The opinions herein are those of the authors and are not to be construed as reflecting the views of the Navy Department, the Uniformed Services University of the Health Sciences or the Department of Defense.

16. We thank Dominique M. Nau for excellent editorial assistance.

17. Requests for reprints should be addressed to: Dr. Val G. Hemming, Uniformed Services University, 4301 Jones Bridge Road, Bethesda, MD 20814.

18. Supported in part by USUHS Grants C08602, C08606 and CIP Grant 76-06886, Naval Hospital Bethesda, Bethesda, MD

19. Received for publication July $22,1982$.

20. Accepted for publication May 11, 1983

\title{
Plasma Concentrations of Vitamin D Metabolites in Premature Infants
}

\author{
T. MARKESTAD ${ }^{(40)}$, L. AKSNES, P. H. FINNE, AND D. AARSKOG \\ Department of Pediatrics, University of Bergen, 5016 Bergen, Norway
}

\section{Summary}

The plasma concentrations of 25-hydroxyvitamin D (OHD), $1,25-(\mathrm{OH})_{2} \mathrm{D}$ and $24,25-(\mathrm{OH})_{2} \mathrm{D}$ were determined in 28 healthy premature infants (median gestational age 33, range 28-36 wk; and median birth weight 1880 , range 900-2350 g) during the first 5-10 wk of life, and in a reference group of 17 young adults. The infants received a vitamin D supplement of $500 \mathrm{IU} / \mathrm{d}$ and a diet low in calcium (Ca) and phophorus $(\mathrm{P})$ compared with that of corresponding intrauterine accretion rates.

The median 25-OHD concentration increased from 11 (range 6-30) $\mathrm{ng} / \mathrm{ml}$ at $1 \mathrm{~d}$ to 27 (range, 15-41) $\mathrm{ng} / \mathrm{ml}$ by 5-10 wk of age $(P<0.01) .1,25-(\mathrm{OH})_{2} \mathrm{D}$ concentrations at age $1 \mathrm{~d}$ were similar to the adult levels (median 37, range 8-64 versus 35 , range $18-58 \mathrm{pg} / \mathrm{ml}$ ), but increased significantly within 1 wk to $48(26-156) \mathrm{pg} / \mathrm{ml}(P=0.01)$, and between 1 and $3-4$ wk of age to $104(58-203) \mathrm{pg} / \mathrm{ml}(P<0.01)$. The levels at 5-10 wk were similar to the 3-4 wk value. $24,25-(\mathrm{OH})_{2} \mathrm{D}$ concentrations were persistently low compared with the adult levels (medians 0.40.5 , range $<0.3-2.1$ versus 1.7 , range $0.4-2.0 \mathrm{ng} / \mathrm{ml}, P<0.01$ ). The relative concentrations, expressed as the ratio of $24,25-$
$(\mathrm{OH})_{2} \mathrm{D}$ to $25-\mathrm{OHD}$, were comparable to those of the adults at birth, but decreased significantly within 2 wk. The data demonstrate that healthy premature infants can produce high plasma levels of $1,25-(\mathrm{OH})_{2} \mathrm{D}$.

The main function of vitamin $\mathrm{D}$ is to enhance intestinal absorption of calcium (Ca) and phophorus (P) (reviews 12, 15). This effect, however, is first achieved after a series of metabolic alterations. The vitamin is first hydroxylated to 25-OHD in the liver, and then to $1,25-(\mathrm{OH})_{2} \mathrm{D}$, which is the principal metabolite with biologic activity, in the kidneys. The circulating concentration of $1,25-(\mathrm{OH})_{2} \mathrm{D}$ is regulated according to the body's need for $\mathrm{Ca}$ and $\mathrm{P}(12,15)$. Other vitamin $\mathrm{D}$ metabolites have also been isolated. $24,25-(\mathrm{OH})_{2} \mathrm{D}$ has received most attention, but its significance remains to be clarified $(12,15)$.

Rickets is not uncommon in premature infants $(7,23,31)$. Several factors are probably of pathogenetic importance $(5,7$, $10,25,30)$, and deficient functions in all aspects of vitamin D metabolism have been implicated, such as: intestinal absorption $(21,31,37)$, hepatic 25 -hydroxylation $(19,21,31)$, renal 1 - 
hydroxylation $(21,31)$, and intestinal responsiveness to $1,25-$ $(\mathrm{OH})_{2} \mathrm{D}(8)$.

The purpose of this investigation was to study the ability of healthy premature infants to form the vitamin $\mathrm{D}$ metabolites $1,25-(\mathrm{OH})_{2} \mathrm{D}$ and $24,25-(\mathrm{OH})_{2} \mathrm{D}$.

\section{MATERIALS AND METHODS}

Twenty-eight premature infants were studied after parental informed consent had been obtained. Median gestational age, assessed by the Dubowitz scoring system (14), was 33 (range 2836) wk, and median birth weight was 1880 (range 900-2350) g. Three infants were small for gestational age (birth weight below the 2.5 percentile), the remaining had appropriate weights. Eight were products of five twin pregnancies. All had an uneventful neonatal course and were on full oral feeds within $7 \mathrm{~d}$ of birth. Eight infants temporarily received $\mathrm{Ca}$ supplements orally or intravenously because of asymptomatic early hypocalcemia, but this was discontinued before the age of $1 \mathrm{wk}$. All received breast milk, but various volumes of a commercial formula were added if breast milk supply was inadequate. The formula was based on cow's milk and contained $67 \mathrm{kcal}, 600 \mathrm{mg} \mathrm{Ca}, 450 \mathrm{mg} \mathrm{P}$, and 450 IU vitamin $D_{3}$ per liter. Mother's milk was estimated to contain $280 \mathrm{mg} \mathrm{Ca}$ and $140 \mathrm{mg} \mathrm{P}$ (4), pooled breast milk 270 $\mathrm{mg} \mathrm{Ca}$ and $130 \mathrm{mg} \mathrm{P}(4,18)$, and both $25 \mathrm{IU}$ vitamin $\mathrm{D}_{3}$ per liter (22). All received an additional daily supplement of $500 \mathrm{IU}$ vitamin $\mathrm{D}_{2}$ given as an aqueous suspension. This was started on d 4 in 20 of the infants, but for reasons unrelated to clinical condition delayed until d 6-14 in the remaining infants. Mineral and vitamin $\mathrm{D}$ intakes were calculated on the basis of accurate records regarding volume and type of milk ingested.

Heparinized venous blood was collected at the following ages: $1 \mathrm{~d}(8-20 \mathrm{~h}, n=14), 3 \mathrm{~d}(n=14), 1 \mathrm{wk}(n=15), 2 \mathrm{wk}(n=15)$, $3-4 \mathrm{wk}(n=14)$, and 5-10 wk $(n=16)$. Seventeen patients had two or more samples drawn. A minimum of trauma from venipuncture was accepted, however, making a serial study unfeasible. The plasma was immediately separated and stored at $-20^{\circ} \mathrm{C}$ until analysis.

Seventeen adults (age 24-36 yr) served as a reference group. In Norway the margarine is fortified with vitamin $D_{3}$ and supplies an average of around $100 \mathrm{IU} / \mathrm{d}$ to adults. No supplements were otherwise given, but they were studied during the summer and consequently exposed to sunshine.

The vitamin D metabolites 25-OHD, 1,25-(OH $)_{2} \mathrm{D}$ and 24,25$(\mathrm{OH})_{2} \mathrm{D}$ were extracted from $0.5-0.6 \mathrm{ml}$ of plasma with diethylether, and purified and separated on open silicic acid columns and by high pressure liquid chromatography according to methods previously described from our laboratory (1). 1,25-(OH $)_{2} \mathrm{D}$ was determined quantitatively by a competitive protein binding assay using duodenal cytosol from rachitic chicks as binding protein (2). 25-OHD and 24,25-(OH $)_{2} \mathrm{D}$ concentrations were assessed similarly by using human serum as binding protein (2). After the specific extraction and purification methods used, we have not found detectable levels of calcidiol lactone in human plasma, a metabolite claimed to interfere with the determination of $24,25-(\mathrm{OH})_{2} \mathrm{D}(13)$. Care was taken to include both vitamin $\mathrm{D}_{2}$ and $\mathrm{D}_{3}$ metabolites in the assays. The intra- and inter-assay coefficients of variation have been found to be 6.3 and $8.5 \%$, respectively for $25-\mathrm{OHD}, 9.7$ and $12.1 \%$ for $1,25-(\mathrm{OH})_{2} \mathrm{D}$, and 7.0 and $9.7 \%$ for $24,25-(\mathrm{OH})_{2} \mathrm{D}$. Plasma Ca was measured by atomic absorption, and $\mathrm{P}$ and alkaline phosphatase by standard laboratory methods $(6,17)$.

Biochemical data were expressed as medians with the range and analyzed statistically using the Wilcoxon's two sample test unless otherwise specified in the text. Correlations were calculated using linear regression analysis.

\section{RESULTS}

The Vitamin D, Ca, and $P$ intakes on well established oral feedings are listed in Table 1 . The values are based on the average daily intakes during a 7-d period.
Table 1. Daily intakes of vitamin D, Ca, and $P$ when oral feedings were well established

\begin{tabular}{lccc}
\hline \multicolumn{1}{c}{ Age (wk) } & 2 & $3-4$ & $5-10$ \\
$\quad$ Number & 15 & 14 & 16 \\
\hline Vitamin D (IU) & & & \\
$\quad$ Median & 507 & 508 & 618 \\
$\quad$ Range & $6-560$ & $503-595$ & $510-685$ \\
Ca intake (mg/kg) & & & \\
$\quad$ Median & 58 & 63 & $96^{*}$ \\
$\quad$ Range & $50-106$ & $45-126$ & $45-117$ \\
P intake (mg/kg) & & & \\
$\quad$ Median & 28 & 36 & $68^{*}$ \\
$\quad$ Range & $26-77$ & $23-94$ & $21-89$ \\
\hline$* P<0.05$ compared with the value at &
\end{tabular}

$* P<0.05$ compared with the value at 2 wk.

The median plasma concentration of Ca was $7.7 \mathrm{mg} / \mathrm{dl}(7.1-$ 9.9) on $\mathrm{d} 1,9.0 \mathrm{mg} / \mathrm{dl}(7.1-12.0)$ on $\mathrm{d} 3$, and $10.0 \mathrm{mg} / \mathrm{dl}(9.5-$ 11.0) on $\mathrm{d} 7$ after birth $(P<0.05$ for all differences). $\mathrm{Ca}$ and $\mathrm{P}$ levels did not change beyond 1 wk of age, and were within normal limits for children (32). Data on alkaline phosphatase concentrations were incomplete in that only 6 infants were studied at the age of $1-2 \mathrm{wk}, 9$ at 3-4 wk, and 12 at 5-10 wk. All values were within the normal range of 275-1050 U/liter for term infants less than 2 mo of age (24), and the median level did not change significantly with time.

For all age groups plasma $1,25-(\mathrm{OH})_{2} \mathrm{D}$ concentrations showed wide variations (Fig. 1). On d 1 of life the values were in the normal adult range (median 37 versus $35 \mathrm{pg} / \mathrm{ml}$ ), but there was a significant increase from $1 \mathrm{~d}$ to $1 \mathrm{wk}$, and further from 1 until $3-4 \mathrm{wk}$ of age (Fig. 1). The levels of 3-4 and 5-10 wk did not differ significantly, and the median value was more than 3 times higher than that of the adults (Fig. 1).

Twelve of the patients were studied at both 1 and $3 \mathrm{~d}$ of age. When these results were tested separately as paired samples, a significant rise in $1,25-(\mathrm{OH})_{2} \mathrm{D}$ was apparent even within this time span (median 41, range 8-64 versus 48 , range $23-104, P=$ 0.02 , Wilcoxon's paired sample test). The median gestational age and birth weight for these infants were similar to those of the total group (33.5, range 30-35 wk and 1720, range 1210-2350 g).

The plasma levels of vitamin D metabolites in the eight patients with early neonatal hypocalcemia did not differ significantly from the rest of the infants. Furthermore, there were no significant correlations between $1,25-(\mathrm{OH})_{2} \mathrm{D}$ and birth weight, gestational age, plasma $\mathrm{Ca}$, or 25-OHD at any age. At 5-10 wk there was, however, a negative correlation between $1,25-(\mathrm{OH})_{2} \mathrm{D}$ levels and plasma $\mathrm{P}(r=-0.59, P<0.025), \mathrm{P}$ intake $(r=-0.48$, $P<0.05)$, and $\mathrm{Ca}$ intake $(r=0.52, P<0.05)$.

The concentrations of $24,25-(\mathrm{OH})_{2} \mathrm{D}$ were low compared with the adult values $(P<0.01$, Table 2$)$, and did not change significantly during the study period. The 25-OHD levels increased, however, and when the $24,25-(\mathrm{OH})_{2} \mathrm{D}$ concentrations were expressed in relative terms as the ratio to $25-O H D$, the values were similar to those found in adults in the immediate postnatal period, but decreased significantly within $2 \mathrm{wk}(P<0.01$, Table $2)$. There were no significant correlations between $24,25-(\mathrm{OH})_{2} \mathrm{D}$ or the ratio of $24,25-(\mathrm{OH})_{2} \mathrm{D}$ to $25 \mathrm{OHD}$, and $\mathrm{Ca}, \mathrm{P}$ or alkaline phosphatase levels, or $\mathrm{Ca}$ and $\mathrm{P}$ intakes.

\section{DISCUSSION}

Previous studies have only given scant informations regarding plasma concentrations of $1,25-(\mathrm{OH})_{2} \mathrm{D}$ and $24,25-(\mathrm{OH})_{2} \mathrm{D}$ in healthy premature infants. Glorieux et al. (16) noted a rise in $1,25-(\mathrm{OH})_{2} \mathrm{D}$ levels during the first $5 \mathrm{~d}$ of life, but only when large doses of vitamin $\mathrm{D}(2100 \mathrm{IU} / \mathrm{d})$ had been given from birth. In sporadic cases of rickets in premature infants both high $(8$, $28,35)$ and low (31) concentrations have been reported. The rapid increase and the high levels attained in our infants indicate 


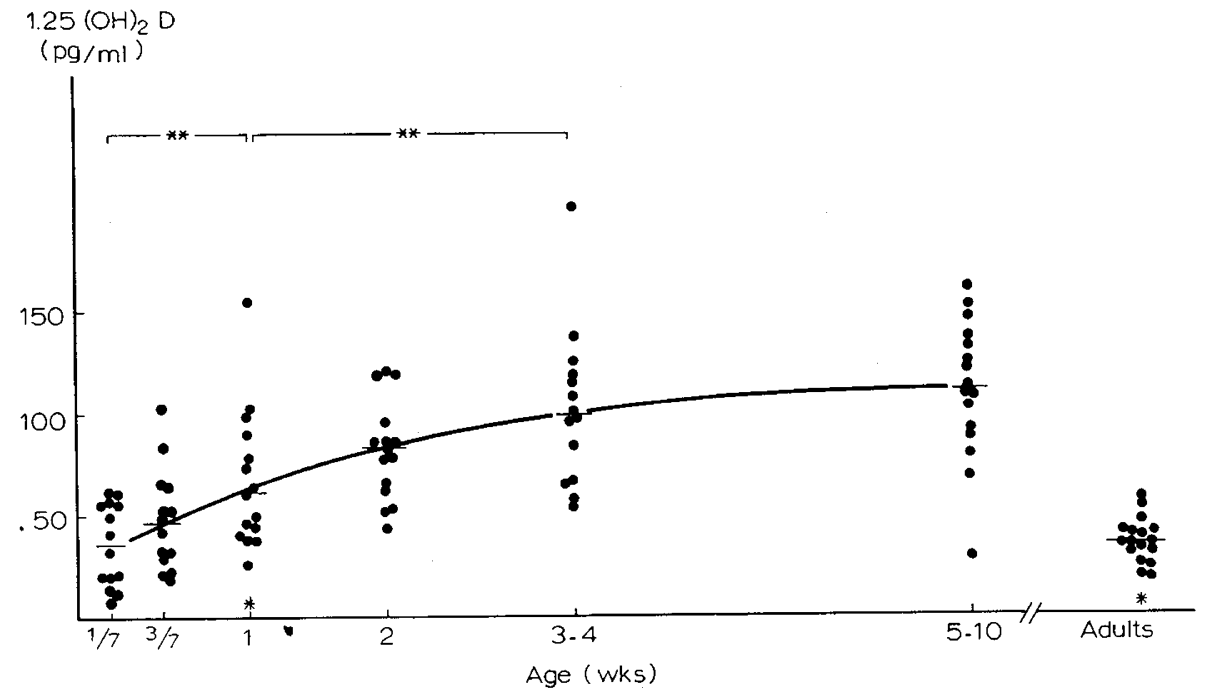

Fig. 1. Plasma concentration of $1,25-(\mathrm{OH})_{2} \mathrm{D}$ with increasing age in premature infants and in an adult reference group. ${ }^{*} P<0.01$ and ${ }^{* *} P<0.05$ (Wilcoxon's two sample test).

Table 2. Plasma concentrations of 25-hydroxyvitamin $\mathrm{D}(\mathrm{OHD})$ and $24,25-(\mathrm{OH})_{2} \mathrm{D}$, and the ratio of $24,25-(\mathrm{OH})_{2} \mathrm{D}$ to $25-\mathrm{OHD}$ with increasing postnatal age

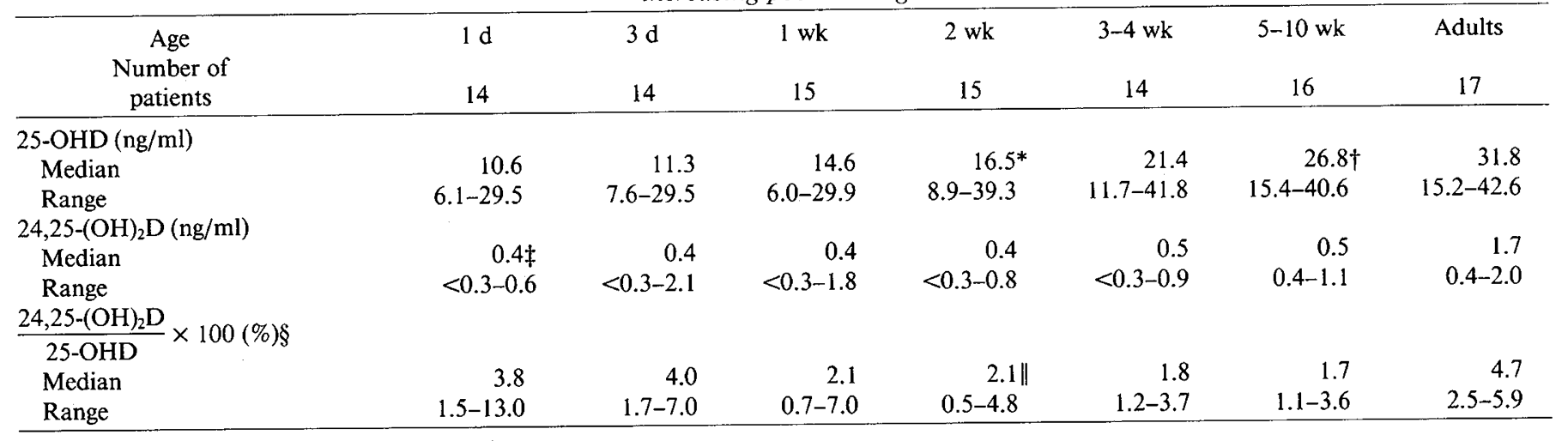

$* P<0.02$ compared with the values at $1 \mathrm{~d}$.

$\dagger P<0.01$ compared with the values at 2 wk.

$\$ P<0.01$ compared with the adult values.

$\S$ Non-detectable concentrations of $24,25-(\mathrm{OH})_{2} \mathrm{D}$ have arbitrarily been assigned a value of half the detection limit. For each of the age groups 1

d to $3-4 \mathrm{wk}$, two to four values are thus calculated.

$\| P<0.01$ compared with the $1-\mathrm{d}$ and adult values.

that premature babies, with as low gestational age as $28 \mathrm{wk}$, have a high potential for $1,25-(\mathrm{OH})_{2} \mathrm{D}$ synthesis.

The vitamin D supplement of $500 \mathrm{IU} / \mathrm{d}$ was sufficient to improve vitamin $\mathrm{D}$ nutritional status as judged by the rising 25 OHD level. The initial median level was, however, below the low normal limit of $12 \mathrm{ng} / \mathrm{ml}$ established for children and adults in our laboratory. In contrast to Glorieux et al. (16) we found no correlation between $25-\mathrm{OHD}$ and $1,25-(\mathrm{OH})_{2} \mathrm{D}$ concentrations to suggest that the low initial 25-OHD levels inhibited the early synthesis of $1,25-(\mathrm{OH})_{2} \mathrm{D}$. This discrepancy may be due possibly to a higher average 25-OHD level in our infants (median 11 versus mean $8 \mathrm{ng} / \mathrm{ml}$ ), and a pharmacologic effect of high vitamin $D$ intake in the referred group (16).

An increased incidence of neonatal hypocalcemia has been reported in infants of vitamin-D-deficient mothers $(11,27)$. The concomitant increases in $1,25-(\mathrm{OH})_{2} \mathrm{D}$ and plasma Ca during the first week of life in our infants lends further support to the notion that vitamin $D$ metabolism is of importance in the perinatal adjustment of mineral homeostasis. The lack of significant correlation between simultaneous $1,25-(\mathrm{OH})_{2} \mathrm{D}$ and $\mathrm{Ca}$ levels suggests, however, that other factors such as parathyroid function or $\mathrm{Ca}$ intake are also important $(20,29)$.

The $\mathrm{Ca}$ and $\mathrm{P}$ intakes of our infants varied according to the relative volumes of breast milk and formula ingested. All received, however, considerably less than the expected intrauterine accretion rates of approximately $150 \mathrm{mg} \mathrm{Ca}$ and $95 \mathrm{mg} \mathrm{P}$ per kg body weight per day (38). Furthermore, Steichen et al. (34) found that a mineral supply similar to our regime was inadequate to prevent osteopenia in small premature infants. The high 1,25$(\mathrm{OH})_{2} \mathrm{D}$ concentrations beyond the perinatal period may therefore represent a normal compensatory effect to ensure maximum $\mathrm{Ca}$ and $\mathrm{P}$ absorption from a relatively mineral deficient diet (12, 15). The negative correlations between $1,25-(\mathrm{OH})_{2} \mathrm{D}$ and plasma $\mathrm{P}$ and mineral intake in the 5-10-wk-old infants support this assumption.

In humans, no physiologic effects of $24,25-(\mathrm{OH})_{2} \mathrm{D}$ have yet been established (12). Details regarding the regulation of its synthesis are also uncertain, but the plasma concentration has been found to correlate positively with the 25-OHD level $(3,33$, $36)$. The relative concentration of $24,25-(\mathrm{OH})_{2} \mathrm{D}$, expressed as the ratio of $24,25-(\mathrm{OH})_{2} \mathrm{D}$ to $25-\mathrm{OHD}$, therefore gives a measure of the degree to which $25-\mathrm{OHD}$ is transformed to $24,25-(\mathrm{OH})_{2} \mathrm{D}$. In older individuals this ratio falls reciprocally to the $1,25-$ $(\mathrm{OH})_{2} \mathrm{D}$ concentration indicating a preference for hydroxylation in the carbon 1 position during periods of high demands for $\mathrm{Ca}$ and $\mathrm{P}$, such as rapid linear growth (3) and pregnancy (26). 
Although we cannot exclude that the low levels of $24,25-(\mathrm{OH})_{2} \mathrm{D}$ in our infants were due to enzyme deficiency because of prematurity, the high levels of $1,25-(\mathrm{OH})_{2} \mathrm{D}$ together with the low $24,25-(\mathrm{OH})_{2} \mathrm{D}$ concentration and the low ratio of $24,25-(\mathrm{OH})_{2} \mathrm{D}$ to $25-\mathrm{OHD}$ in rapidly growing premature infants are in agreement with such a model, and indicate that the vitamin $D$ metabolism is adjusted to meet these infants' needs for maximum $\mathrm{Ca}$ and $\mathrm{P}$ retention.

\section{REFERENCES AND NOTES}

1. Aksnes, L.: Quantitation of the main metabolites of vitamin D in a single serum sample. I. Extraction, separation and purification of metabolites. Clin. Chim. Acta., 104: 133 (1980).

2. Aksnes, L.: Quantitation of the main metabolites of vitamin D in a single serum sample. II. Determination by UV-absorption and competitive protein binding assays. Clin. Chim. Acta, 104: 147 (1980)

3. Aksnes, L. and Aarskog, D.: Plasma concentrations of vitamin D metabolites in puberty: effect of sexual maturation and implications for growth. J. Clin. Endocrinol. Metab., 55: 94 (1982).

4. Atkinson, S. A., Radde, I. C., Chance, G. W., Bryan, M. H., and Anderson, G. H.: Macro-mineral content of milk obtained during early lactation from mothers of premature infants. Early Hum. Dev., 4: 5 (1980).

5. Bosley, A. R. J., Verrier-Jones, E. R., and Campbell, M. J.: Aetiological factors in rickets of prematurity. Arch. Dis. Child., 55:683 (1980)

6. Bowers, G. N. and McComb, R. B.: A continuous spectrophotometric method for measuring the activity of serum alkaline phosphatase. Clin. Chem., 12: 70 (1966).

7. Callenbach, J. C., Sheehan, M. B., Abramson, S. J., and Hall, R. T.: Etiologic factors in rickets of very low-birth-weight infants. J. Pediatr., 98: 800 (1981)

8. Chesney, R. W., Hamstra, A. J., and DeLuca, H. F.: Rickets of prematurity. Am. J. Dis. Child., 135: 34 (1981).

9. Chudley, A. E., Brown, D. R., Holzman, I. R., and Oh, K. S.: Nutritional rickets in 2 very low birthweight infants with chronic lung disease. Arch. Dis. Child., 55: 687 (1980)

10. Cifuentes, R. F., Kooh, S. W., and Radde, I. C.: Vitamin D deficiency in a calcium-supplemented very low-birth-weight infant. J. Pediatr., 96: 252 (1980).

11. Cockburn, F., Belton, N. R., Purvis, R. J., Giles, M. M., Brown, F. K., Turner T. L., Wilkinson, E. M., Forjar, F. B., Barrie, W. F. M., McKay, G. S., and Pocock, S. F.: Maternal vitamin D intake and mineral metabolism in mothers and their newborn infants. Br. Med. J., 2: 11 (1980).

12. Deluca, H. F.: Vitamin D. Metabolism and function. Monographs on Endocrinology. (Springer-Verlag, New York 1979).

13. Deluca, H. F., and Schnoes, H. K.: Recent developments in the metabolism of vitamin D. In: Norman, A. W., Schaefer, K., Herrath, D. V., Grigoleit, H.G., Coburn, J. W., DeLuca, H. F., Mawer, E. B., and Suda, T.: Vitamin D, Basic research and its clinical application. pp. 445-458 (Walter de Gruyter, Berlin-New York, 1979).

14. Dubowitz, L. M. S., Dubowitz, V., and Goldberg, C.: Clinical assessment of gestational age in the newborn infant. J. Pediatr., $77: 1$ (1970).

15. Fraser, D. R.: Regulation of the metabolism of vitamin D. Physiol. Rev, 60: 551 (1980).

16. Glorieux, F. H., Salle, B. L., Delvin, E. E., and David, L.: Vitamin D metabolism in preterm infants: serum calcitriol values during the first five days of life. J. Pediatr., 99: 640 (1981).

17. Gomori, G.: A modification of the colorometric phosphorus determination for use with the photoelectric colorimeter. J. Lab. Clin. Med., 27: 955 (1942).

18. Greer, F. R., Tsang, R. C., Levin, R. S., Searcy, J. E., Wu, R., and Steichen, J. $\mathrm{J}$. : Increasing serum calcium and magnesium concentrations in breast-fed infants: longitudinal studies of minerals in human milk and in sera of nursing mothers and their infants. J. Pediatr., 100: 59 (1982).
19. Hillman, L. S. and Haddad, J. G.: Perinatal vitamin D metabolism. J. Pediatr., 86: 928 (1975)

20. Hillman, L. S., Rojanasathit, S., Slatopolsky, E., and Haddad, J. G.: Serial measurements of serum calcium, magnesium, parathyroid hormone, calcitonin, and 25-hydroxy vitamin $\mathrm{D}$ in premature and term infants during the first week of life. Pediatr. Res., 11: 739 (1977).

21. Hoff, N., Haddad, J. G., Teitelbaum, S., McAlister, W., and Hillman, L. S.: Serum concentrations of 25 -hydroxyvitamin $D$ in rickets of extremely premature infants. J. Pediatr., 94: 460 (1979).

22. Hollis, B. W., Roos, B. A., Draper, H. H., and Lambert, P. W.: Vitamin D and its metabolites in human and bovine milk. J. Nutr., 111: 1240 (1981).

23. Kulkarni, P. B., Hall, R. T., Rhodes, P. G., Sheehan, M. B., Callenbach, J. C., Germann, D. R., and Abramson, S. J.: Rickets in very low-birth-weight infants. J. Pediatr., 96: 249 (1980)

24. Landaas, S., Skrede, S., and Steen, J.: Reference levels for serum enzymes, plasma proteins and lipids during infancy. Tidsskr. Nor. Laegeforen., 101: 257 (1981).

25. Lewin, P. K., Reid, M., Reilly, B. J., Swyer, P. R., and Fraser, D.: Iatrogenic rickets in low-birth-weight infants. J. Pediatr., 78: 207 (1971).

26. Reiter, E. O., Braunstein, G. D., Vargas, A., and Root, A. W.: Changes in 25hydroxyvitamin D and 24,25-dihydroxyvitamin D during pregnancy. Am. J. Obstet. Gynecol., 135: 227 (1979).

27. Rosen, J. F., Roginsky, M., Natheson, G., and Finberg, L.: 25-hydroxyvitamin D. Plasma levels in mothers and their premature infants with neonatal hypocalcemia. Am. J. Dis. Child. 127: 220 (1974)

28. Rowe, J. C., Wood, D. H., Rowe, D. W., and Raisz, L. G.: Nutritional hypophosphatemic rickets in a premature infant fed breast milk. N. Engl. J. Med., 300: 293 (1979).

29. Salle, B. L., David, L., Glorieux, F. H., Delvin, E., Senterre, J., and Renaud, H.: Early oral administration of vitamin $D$ and its metabolites in premature neonates. Effect on mineral homeostasis. Pediatr. Res., 16: 75 (1982).

30. Sagy, M., Birenbaum, E., Balin, A., Orda, S., Barzilay, Z., and Brish, M.: Phosphate-depletion syndrome in a premature infant fed human milk. J. Pediatr., 96: 683 (1980)

31. Seino, Y., Ishii, T., Shimotsuji, T., Ishida, M., and Yabuuchi, H.: Plasma active vitamin $D$ concentration in low birthweight infants with rickets and its response to vitamin D treatment. Arch. Dis. Child., 56: 628 (1981).

32. Sovik, O., Brockmeier, F., Koller, M-E., and Skagseth, P. A.: Clinical chemistry in childhood. Reference values. Tidskr. Nor. Laegeforen., 99: 165 (1979).

33. Stanbury, S. W., Taylor, C. M., Lumb, G. A., Mawer, E. B., Berry, J., Hann, $\mathrm{J}$., and Wallace, J.: Formation of vitamin $\mathrm{D}$ metabolites following correction of human vitamin D deficiency. Mineral Eiectrolyte Metab., 5: 212 (1981)

34. Steichen, J. J., Gratton, T. L., and Tsang, R. C.: Osteopenia of prematurity: the cause and possible treatment. J. Pediatr., 96: 528 (1980).

35. Steichen, J. J., Tsang, R. C., Greer, F. R., Ho, M., and Hug, G.: Elevated serum 1,25 dihydroxyvitamin $\mathrm{D}$ concentrations in rickets of very low-birthweight infants. J. Pediatr., 99: 293 (1981).

36. Weisman, Y., Reiter, E., and Root, A.: Measurement of 24,25-dihydroxyvitamin D in sera of neonates and children. J. Pediatr. $91: 904$ (1977).

37. Wolf, H., Gräf, V., and Offermann, G.: The vitamin $D_{3}$ requirement for premature infants. In: Anthony W. Norman et al.: Vitamin D, Basic Research and Its Clinical Application. pp. 349-352 (Walter De Gruyter, BerlinNew York, 1979).

38. Ziegler, E. E., O'Donnell, A. M., Nelson, S. E., and Fomon, S. J.: Body composition of the reference fetus. Growth, 40:329 (1976).

39. Analyses of plasma $\mathrm{Ca}, \mathrm{P}$ and alkaline phosphatase were performed at The Department of Clinical Biochemistry, Haukeland sykehus, University of Bergen, with the technical assistance of Mr. Kaare Soensteboe. The EDPsection of the Medical Faculty, University of Bergen, gave helpful suggestions regarding statistical methods.

40. Requests for reprints should be addressed to: Dr. T. Markestad, Department of Pediatrics, N-5016 Haukeland sykehus, Bergen, Norway.

41. This research was supported by The Norwegian Research Council for Science and the Humanities, and the Nestlé Nutrition Research Grant Program.

42. Received for publication October 18, 1982.

43. Accepted for publication April 19, 1983. 